Chapter 12

\title{
Synthesis and Characterization of Fe-Imogolite as an Oxidation Catalyst
}

\section{Masashi Ookawa}

Additional information is available at the end of the chapter

http://dx.doi.org/10.5772/48171

\section{Introduction}

Imogolite is a hydrated aluminosilicate with a unique tubular structure, which is found in volcanic ash soil and is shown in Figure 1. It was first discovered in glassy volcanic ash soil in Japan and was named after the soil in Hitoyoshi, Kumamoto Prefecture [1]. Its chemical composition is $(\mathrm{OH})_{3} \mathrm{Al}_{2} \mathrm{O}_{3} \mathrm{Si}(\mathrm{OH})$.

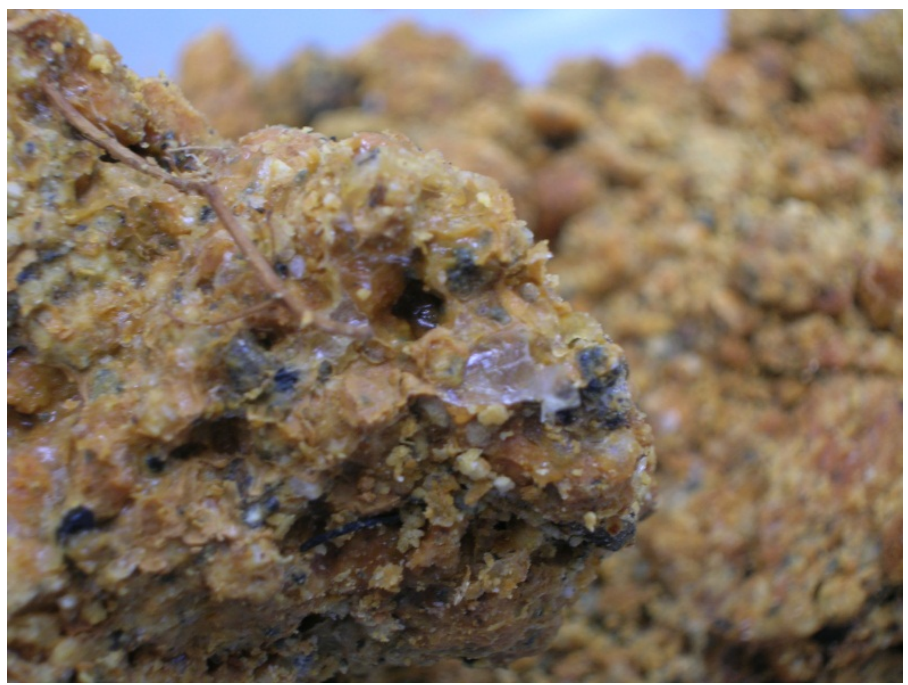

Figure 1. Photograph of natural imogolite films in soil.

The tubular structure of imogolite was proposed by Cradwick et al. [2] based on results from electron diffraction observation and is shown in figure 2. The tube wall consists of a 
single continuous $\mathrm{Al}(\mathrm{OH})_{3}$ (gibbsite) sheet and orthosilicate anions $\left(\mathrm{O}_{3} \mathrm{SiOH}\right.$ groups) associated with each vacant octahedral site of the gibbsite sheet. The imogolite has an outer diameter of ca. $2 \mathrm{~nm}$ and an inner diameter of ca. $1 \mathrm{~nm}$.

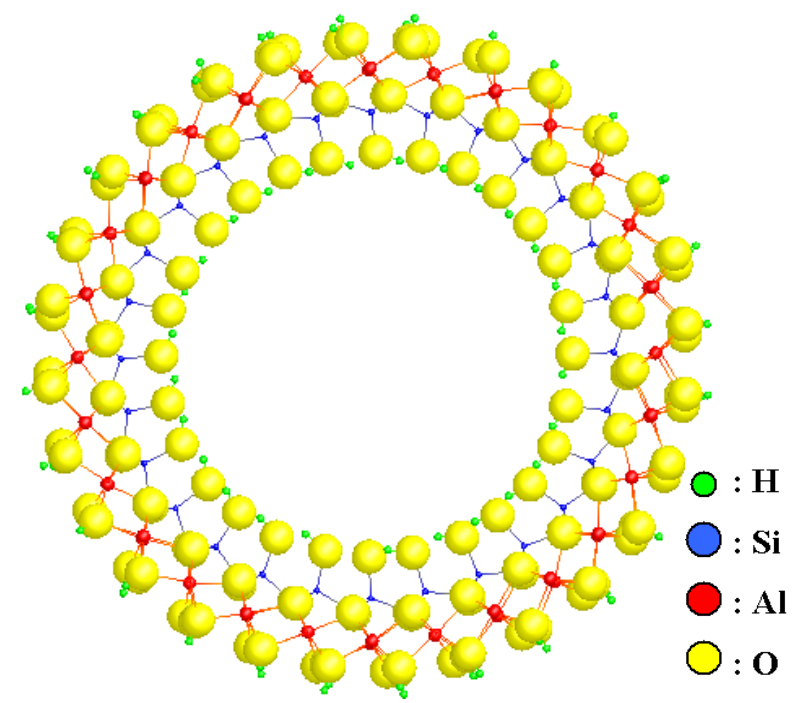

Figure 2. A cross-section of the structural model of an imogolite tube.

Recently, imogolite has drawn a new attention as a new nano-material because of its unique nano-scale tubular structure similar to that of a single-walled carbon nanotube [3]. Studies on synthesis [4-9], mechanisms of formation [10], structural evolution [11, 12], stability [13, 14], electronic states [14, 15] and application have been carried out. Proposed applications, such as a polymer composite [16,17], a fuel gas storage [18], an absorbent [19], an exchange material for heat pump system [20], a humidity-controlling material [6] and an antideweling material [6] have been discussed.

Application as a catalyst or a catalyst support also attracts attention because it is expected to have a shape-selective characteristic property as molecular sieving zeolites due to its unique tubular structure. However, few investigations [21, 22] have been reported using natural imogolite as a catalyst because the extraction of pure imogolite from the soil is difficult and time consuming [21]. Therefore, synthesis of imogolite has become necessary in order to utilize it as a functional material.

We synthesized imogolite containing $\mathrm{Fe}^{3+}$ ions (Fe-imogolite) using $\mathrm{NaSiO}_{4}, \mathrm{FeCl}_{3}$ and $\mathrm{AlCl}_{3}$ to investigate its catalytic properties [23]. Because of its chemical stability, an incorporation of another element is necessary to generate a chemical function. We found that it served as a catalyst of liquid-phase oxidation reactions of some hydrocarbons.

In this chapter, the synthetic methods, characterization and the general properties of imogolite is described at first. And then the characterization and catalytic properties of Feimogolite obtained from our researches is described. 


\section{Synthetic imogolite}

In the latter half of the 1970's, synthesis of imogolite was succeeded from a dilute solution. Recently, various synthesis methods have been investigated and many characterizations have been carried out. In this section, synthesis methods, structural characterization and catalytic properties of synthetic imogolite are described.

\subsection{Synthesis method of imogolite}

Farmer et al. reported [24] the synthesis method of imogolite in 1977. Imogolite was synthesized from a dilute solution containing of hydroxyaluminum cations $(2.4 \mathrm{mmol} \mathrm{L}-1)$ and orthosilicic acid $\left(1.4 \mathrm{mmol} \mathrm{L}^{-1}\right)$. Afterward, the solution was adjusted to $\mathrm{pH} 5$ with sodium hydroxide, $1 \mathrm{mmol} \mathrm{L}^{-1}$ of hydrochloric acid solution and $2 \mathrm{mmol} \mathrm{L}^{-1}$ of acetic acid. Imogolite was obtained in this solution by heating it near the boiling point. Wada et al. [25] later also investigated the effects of $\mathrm{Al}-\mathrm{to}-\mathrm{OH}^{-}$(as sodium hydroxide) ratio to synthesizing imogolite and allophane using a dilute inorganic solution.

A diluted inorganic solution is necessary to form imogolite in these methods, because preventing the condensation of orthosilicic acid and the formation inhibition of it by anions is important to form the nanotube structure. However, it is difficult to obtain a large sample. Suzuki et al. [6] developed a synthetic method of producing imogolite using a concentrated inorganic solution. Sodium orthosilicate was used as a starting material to prevent the condensation of orthosilicic acid. Furthermore, a desalination process is carried out by centrifugation. We have synthesized Fe containing imogolite based on improving Suzuki's method which will be described below in detail.

More recently, new synthesis methods of imogolite have been reported. Levard et al. [8] synthesized it from a decimolar concentration solution at $95{ }^{\circ} \mathrm{C}$ for 60 days. Abidin et al. [9] proposed a new supplying method of a silicon source using colloidal silica for the synthesis of imogolite.

\subsection{Characterization of imogolite}

\subsubsection{Morphology}

Transmission electron microscopy (TEM) or scanning electron microscopy (SEM) is used mostly in order to observe the morphology and structure of imogolite nanotubes. Figure 3 shows an SEM image of synthetic imogolite.

Bursill et al. [2] have observed the various aggregations of them such as randomly oriented single tube, close-packed arrays or fiber bundles by high resolution TEM.

On the other hand, atomic force microscopy (AFM) is a powerful tool to investigate them under ambient conditions. The tapping-mode AFM especially shows the morphological features of the synthetic imogolite clearly $[26,27]$. Figure 4 shows the tapping mode AFM image of synthetic imogolite. Fibrous materials with a length of $100-1000 \mathrm{~nm}$ can be observed in this image. 


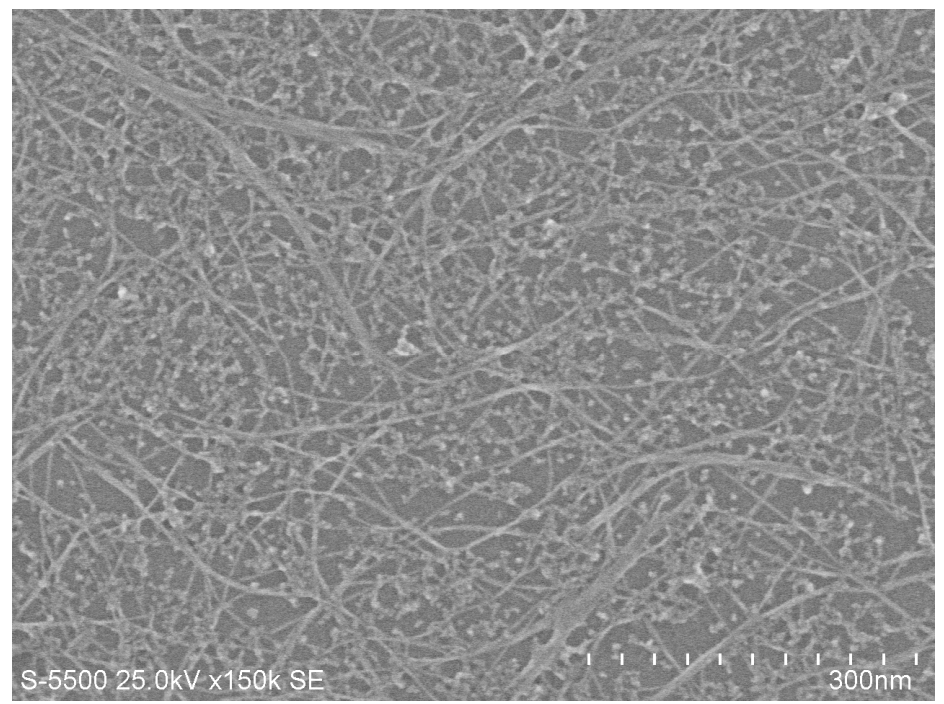

Figure 3. The FE-SEM image of synthetic imogolite.

\subsubsection{Structural characterization}

The analytical methods, such as X-ray diffraction (XRD), infrared (IR) spectroscopy and solid state nuclear magnetic resonance (NMR) are used in order to identify or characterize imogolite. In this section, the features of imogolite obtained using these analytical methods are mentioned.

The XRD profiles which were obtained by $\mathrm{Cu} \mathrm{K} \alpha$ irradiation are given in Figure 5. Imogolite is characterized by three broad peaks in the low angle region. There are three peaks at $2 \theta=$ $5.1^{\circ}, 11^{\circ}$ and $15.6^{\circ}$ in the XRD profile of natural imogolite and at $2 \theta=4.6^{\circ}, 9.6^{\circ}$ and $14.3^{\circ}$ in that of synthetic imogolite. The difference in peak position is due to the difference in the diameter of a tube of a natural and synthetic imogolite [7, 24]. The diameter of $1.8-2.2 \mathrm{~nm}$ in natural imogolite [1] and $2.7-3.2 \mathrm{~nm}$ in synthetic imogolite [25] were reported.

FT-IR spectra of Natural and synthetic imogolite, which are shown in figure 6, have a characteristic absorption that appears as a doublet at around $1000 \mathrm{~cm}^{-1}$. These absorptions are attributed to Si-O (higher frequency) and Si-O-Al (lower frequency) stretching [28]. These samples also have some absorption bands in the region from $400 \mathrm{~cm}^{-1}$ to $750 \mathrm{~cm}^{-1}$. The absorption bands at $685 \mathrm{~cm}^{-1}, 563 \mathrm{~cm}^{-1}$ and $427 \mathrm{~cm}^{-1}$ in natural imogolite arise from various Al-O vibrations [29].

Imogolite is also characterized by ${ }^{29} \mathrm{Si}$ and ${ }^{27} \mathrm{Al}$ solid state NMR [30-34]. Magic angle spinning (MAS) techniques are used in general in order to obtain a high resolution NMR spectrum of sold state. Goodman et al. [34] have carried out ${ }^{29} \mathrm{Si}$ and ${ }^{27} \mathrm{Al}$ MAS NMR measurements of synthetic imogolite. The peak is observed at $-78.8 \mathrm{ppm}$ in ${ }^{29} \mathrm{Si}$ MAS NMR spectrum of it as well as natural imogolite. Barron et al. [30] have shown that the observed 


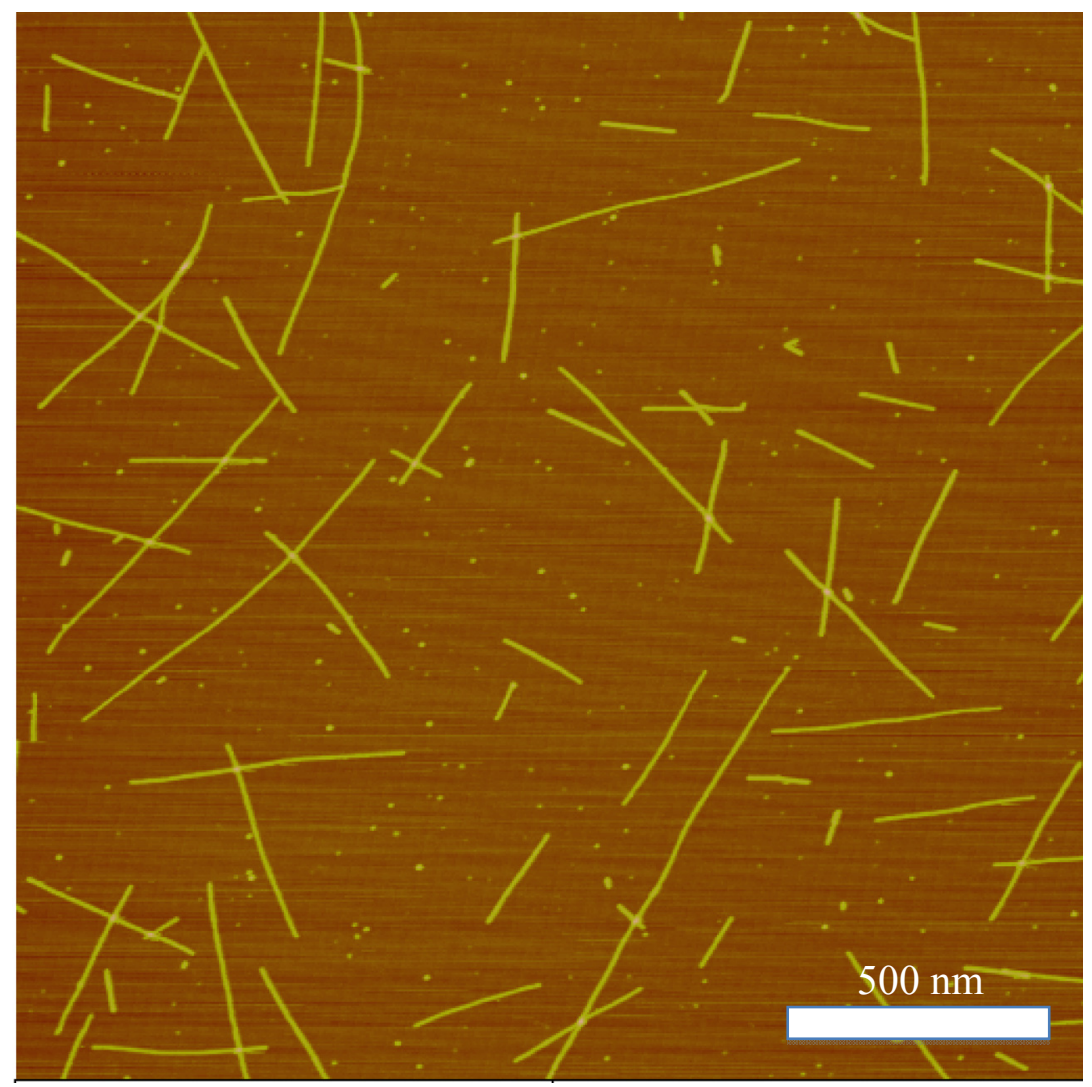

Figure 4. The tapping mode AFM image of synthetic imogolite.

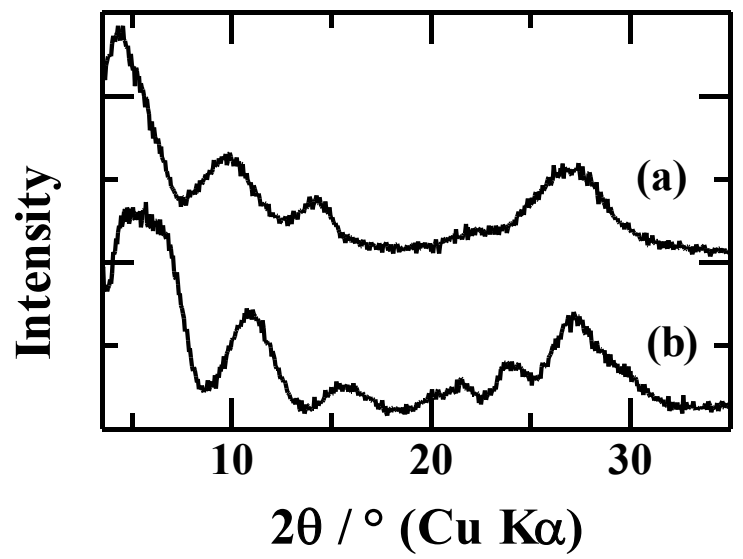

Figure 5. XRD profiles of synthetic imogolite (a) and natural imogolite (b). 
chemical shift of natural imogolite is consistent with silicon tetrahedra which are isolated by coordination through oxygen with three aluminum atoms and one proton. On the other hand, ${ }^{27} \mathrm{Al}$ MAS NMR spectrum of imogolite has one peak at $0 \mathrm{ppm}$ and it is attributed to the six coordinated octahedral $\mathrm{Al}^{3+}$ species [31-34].

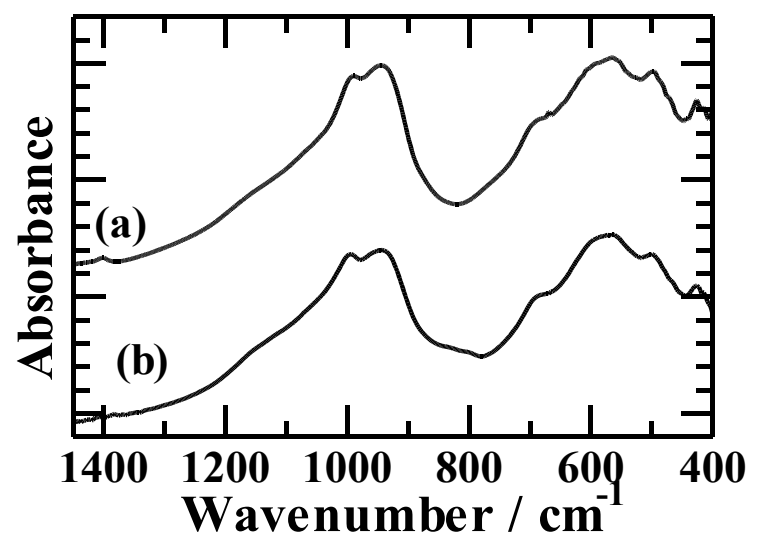

Figure 6. FT-IR spectra of synthetic imogolite (a) and natural imogolite (b).

\subsubsection{Thermal transformation of synthetic imogolite}

The differential thermal analysis (DTA) and thermo gravimetric analysis (TGA) traces of synthetic imogolite are shown in Figure 7. Two broad endothermic peaks with a weight loss and an exothermic peak without a weight change were observed.

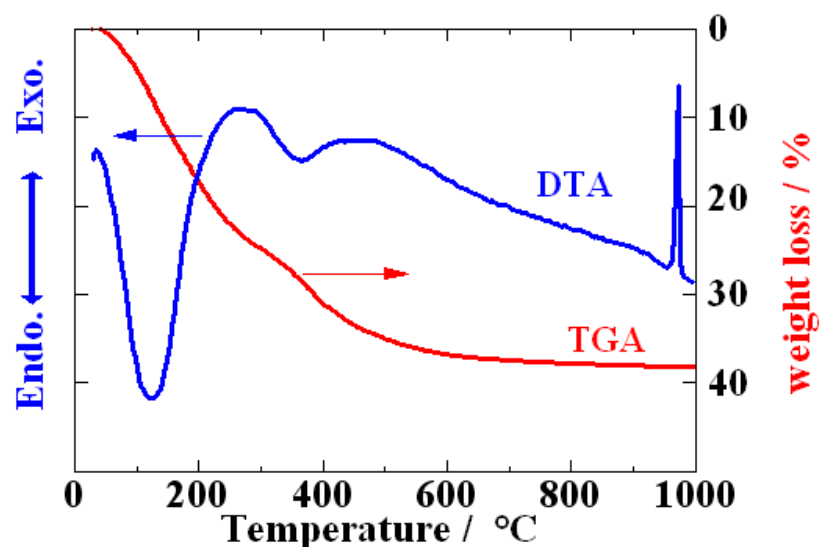

Figure 7. DTA-TGA curves of synthetic imogolite.

MacKenzie et al. [31] investigated thermal transformation of natural imogolite by using DTA-TGA, ${ }^{29}$ Si MAS NMR and ${ }^{27}$ Al MAS NMR and proposed the structural models which were changed by heating. The results of DTA-TGA showing thermal transformation of 
imogolite are explained based on their literature. The endothermic peaks at $110{ }^{\circ} \mathrm{C}$ and $400{ }^{\circ} \mathrm{C}$ were attributed to the loss of adsorbed water and dehydroxylation, respectively. Amorphism of imogolite occurred by these dehydroxylations. The exothermic peak at 950 ${ }^{\circ} \mathrm{C}$ was attributed to crystallization to mullite $\left(\mathrm{Al}_{6} \mathrm{Si}_{2} \mathrm{O}_{13}\right)$. Donkai et al. [11] investigated thermal transformation of natural imogolite up to $1600{ }^{\circ} \mathrm{C}$ using XRD and IR and reported the formation of tridymite $\left(\mathrm{SiO}_{2}\right)$ with mullite crystals above $1200{ }^{\circ} \mathrm{C}$. Hatakeyama et al. [34] investigated the transformation heat-treated synthetic imogolite by using ${ }^{27} \mathrm{Al}$ MAS NMR and ${ }^{27} \mathrm{Al}$ multiple-quantum magic-angle-spinning (MQMAS) NMR. These results show five- and four-coordinated $\mathrm{Al}$ is formed above $350{ }^{\circ} \mathrm{C}$ in amorphous materials clearly.

\subsubsection{Catalytic properties}

It has been known that imogolite has surface acidity [35]. The acid strength of it is increased by heat treatment. Natural imogolite calcined at various temperatures were used as catalysts for the isomerization of 1-butene [21]. This reaction proceeded effectively over samples calcined at $400{ }^{\circ} \mathrm{C}$. The decomposition reaction of organic peroxides also was investigated using $\mathrm{Cu}^{2+}$ loaded imogolite calcined at $500{ }^{\circ} \mathrm{C}$. Furthermore, it was mentioned that imogolite calcined at temperature up to $750{ }^{\circ} \mathrm{C}$ exhibited the shape selective adsorption. Bonelli et al. [36] have studied in situ IR spectroscopy of synthetic imogolite which adsorbed $\mathrm{CO}$, ammonia, methanol or phenol and catalytic tests using gas-phase phenol reactions with methanol. They showed that a small amount of $\mathrm{Al}^{3+}$ Lewis acid sites to adsorb $\mathrm{CO}$ existed, the adsorbed ammonia on imogolite evacuated at $150{ }^{\circ} \mathrm{C}$ was observed as $\mathrm{NH}_{4}{ }^{+}$species and, in addition, a probe such as $\mathrm{CO}$, ammonia, methanol or phenol could interact with inner silanols. The reaction of phenol with methanol was performed over imogolite after thermal treatment at $300{ }^{\circ} \mathrm{C}$ and at $500{ }^{\circ} \mathrm{C}$. The activity was shown over samples heated at $500{ }^{\circ} \mathrm{C}$ and o-cresol and anisole were obtained as products.

We have investigated the acidic property of imogolite without heat treatment [37]. At first, we attempted an isomerization reaction of $\alpha$-pinene on synthetic imogolite. It is known that the isomerization products of $\alpha$-pinene depend on the acid or base property of the catalyst. In the case of acid catalysts, $\alpha$-pinene isomerize to limonene, camphene and tricyclene [38]. Prior to the reaction imogolite was dried at $120{ }^{\circ} \mathrm{C}$ for 12 hours. The isomerization reaction of $\alpha$-pinene was carried out at $80{ }^{\circ} \mathrm{C}$ for 3 hours or 24 hours using an evacuated batch reactor. In a typical experiment, the reactor was loaded with $12.6 \mathrm{mmol}$ of $\alpha$-pinene and 50 $\mathrm{mg}$ of catalyst. The $\alpha$-pinene did not react on it. It was reported that imogolite had a weak acid property, however it was not detected in this reaction.

Although isomerization of $\alpha$-pinene did not occurre, some oxidation products of it were detected slightly. So the oxidation reaction of cyclohexene using hydrogen peroxide was carried out to test the possibility as an oxidation catalyst.

In a typical catalytic experiment for oxidation [38], the reaction was carried out by using 25 mmol of cyclohexene, $25 \mathrm{mmol}$ of $\mathrm{H}_{2} \mathrm{O}_{2}(30 \mathrm{wt} \%)$ and $30 \mathrm{ml}$ of acetic acid or acetonitrile as a 
solvent with $100 \mathrm{mg}$ of catalyst under being stirred at $50{ }^{\circ} \mathrm{C}$. The results of the oxidation reaction of cyclohexene with $\mathrm{H}_{2} \mathrm{O}_{2}$ are listed in Table 1. Without a catalyst the oxidation products such as trans-1,2-cyclohexanediol, cis-1,2-cyclohexanediol and 2-cyclohexene-1-ol were observed using acetic acid as solvent. With imogolite the yield of these oxidation products was increased, but the selectivity was almost the same as the control experiment. This result indicates that imogolite has the potential of concentration and acts as a field of reaction to increase collision frequency.

\begin{tabular}{ccccc}
\hline \multicolumn{2}{c}{ Product } & 1-ol & trans-diol & cis-diol \\
\hline Yield & imogolite & 32.3 & 21.5 & 2.9 \\
\cline { 2 - 5 } / \% & no catalyst & 14.6 & 12.0 & 1.3 \\
\hline Selectivity & imogolite & 56.9 & 38.0 & 5.1 \\
\cline { 2 - 5 }$/ \%$ & no catalyst & 52.3 & 43.2 & 4.5 \\
\hline
\end{tabular}

Table 1. Oxidation of cyclohexene with $\mathrm{H}_{2} \mathrm{O}_{2}$ over imogolite in acetic acid as a solvent. [38] Reaction condition: temperature $50^{\circ} \mathrm{C}$, time $6 \mathrm{~h}$, imogolite $100 \mathrm{mg}$ 1-ol : 2-cyclohexene-1-ol, trans-diol : trans-1,2-cyclohexanediol, cis-diol: 1,2-cyclohexanediol

In the case of using acetonitrile as the solvent, the oxidation products were not detected for 27 hours of reaction time. In the case of imogolite, 2-cyclohexene-1-ol and 1,2epoxycyclohexene were produced with $0.5 \%$ and $0.8 \%$ yields, respectively. This results shows that imogolite has the possibility as an oxidation catalyst.

\section{Fe-imogolite}

Although we found the new possibility of synthetic imogolite as an oxidation catalyst, a chemical modification of imogolite like an introduction of $\mathrm{Fe}^{3+}$ ion was necessary to promote the reaction because imogolite is chemically stable. In this section, our results of the synthetic method, characterization and catalytic test of Fe-imogolite are described.

\subsection{Synthesis of Fe-imogolite}

Fe-imogolite was synthesized based on improving Suzuki's method [6, 7]. The typical method [23] is described here and its flowchart is shown in Scheme 1.

1. We prepared $100 \mathrm{~mL}$ of $0.15 \mathrm{~mol} \mathrm{~L}^{-1}$ aqueous solutions consist of $\mathrm{FeCl}_{3}$ and $\mathrm{AlCl}_{3}$ with $\mathrm{x}$ $=0.05(\mathrm{x}=\mathrm{Fe} / \mathrm{Al}+\mathrm{Fe}$, atomic ratio $)$. Another way of saying, $0.00075 \mathrm{~mol} \mathrm{FeCl}_{3} \cdot 6 \mathrm{H}_{2} \mathrm{O}$ and $0.01425 \mathrm{~mol} \mathrm{AlCl}_{3} \cdot 6 \mathrm{H}_{2} \mathrm{O}$ were dissolved in $100 \mathrm{~mL}$ of water.

2. $100 \mathrm{~mL}$ of $0.1 \mathrm{~mol} \mathrm{~L}^{-1} \mathrm{Na}_{4} \mathrm{SiO}_{4}$ aqueous solution was prepared.

3. $\mathrm{Na}_{4} \mathrm{SiO}_{4}$ aqueous solution was added to $\mathrm{AlCl}_{3}$ and $\mathrm{FeCl}_{3}$ mixture and the solution was stirred for 90 minutes.

4. $0.1 \mathrm{~mol} \mathrm{~L}^{-1} \mathrm{NaOH}$ aqueous solution was added to the solution consist of $\mathrm{Na}_{4} \mathrm{SiO}_{4}, \mathrm{FeCl}_{3}$ and $\mathrm{AlCl}_{3}$ at the rate of $1.0 \mathrm{~mL} \mathrm{~min}^{-1}$ under stirring until the $\mathrm{pH}$ of the mixture become 5.5 . 
5. The salt-free precursor was obtained from thick solution by centrifugal separation three times.

6. It was dispersed in $2 \mathrm{~L}$ of water and $40 \mathrm{~mL}$ of $0.1 \mathrm{~mol} \mathrm{~L}^{-1} \mathrm{HCl}$ was added.

7. The solution was stirred for two hours at room temperature.

8. It was aged at $100{ }^{\circ} \mathrm{C}$ for 40 hours.

9. This aging solution was dialyzed and then dried at $100{ }^{\circ} \mathrm{C}$ for two days.

10. The film-like Fe-imogolite was obtained.

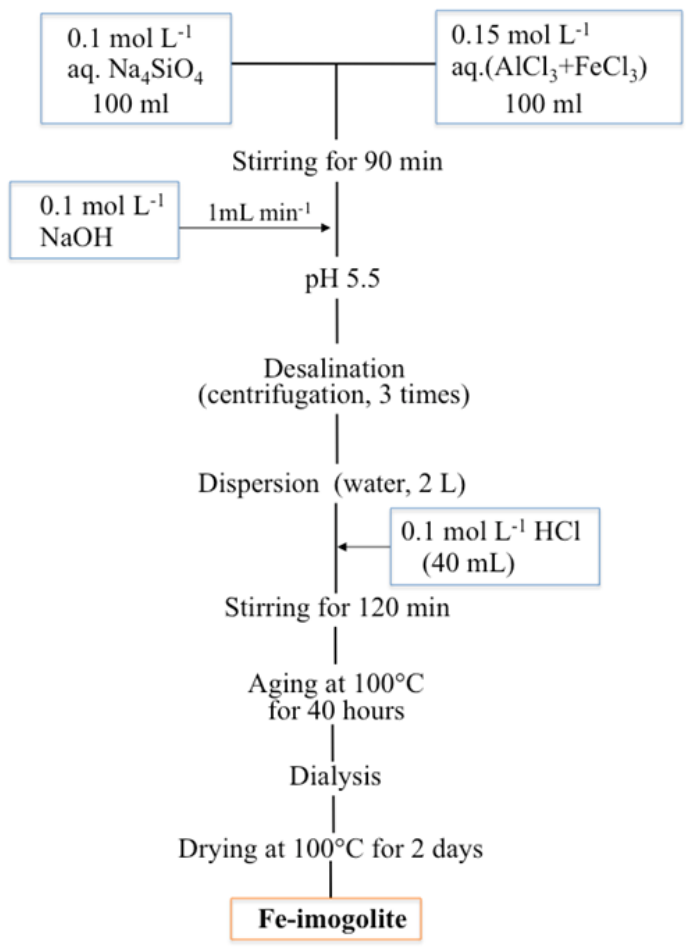

Scheme 1. Flowchart of a synthetic method of Fe-imogolite.

\subsection{Characterization of Fe-imogolite}

Fe containing samples with $\mathrm{x}=0,0.05,0.1$ were prepared in order to survey the effect of $\mathrm{Fe}^{3+}$ contents in starting solutions to formation of imogolite nanotubes,. The XRD profiles and IR spectra of these samples are shown in Figure 8.

As mentioned above, imogolite $(x=0)$ was characterized by three broad peaks in the low angle region of the XRD profile and a doublet at around $1000 \mathrm{~cm}^{-1}$ in the FT-IR spectrum. In the case of $x=0.1$, it lacks the three broad peaks in XRD and a doublet in FT-IR, meaning the sample does not have the imogolite structure. In the case of $x=0.05$, the XRD profile and FTIR spectrum were similar to the imogolite. The intensity of the three broad peaks is weaker 
than that of imogolite because XRD measurements were carried out using $\mathrm{Cu} K \alpha$ irradiation. The color and the profiles of XRD and FT-IR indicate the sample with $\mathrm{x}=0.05$ is considered Fe containing imogolite and is thus called Fe-imogolite.
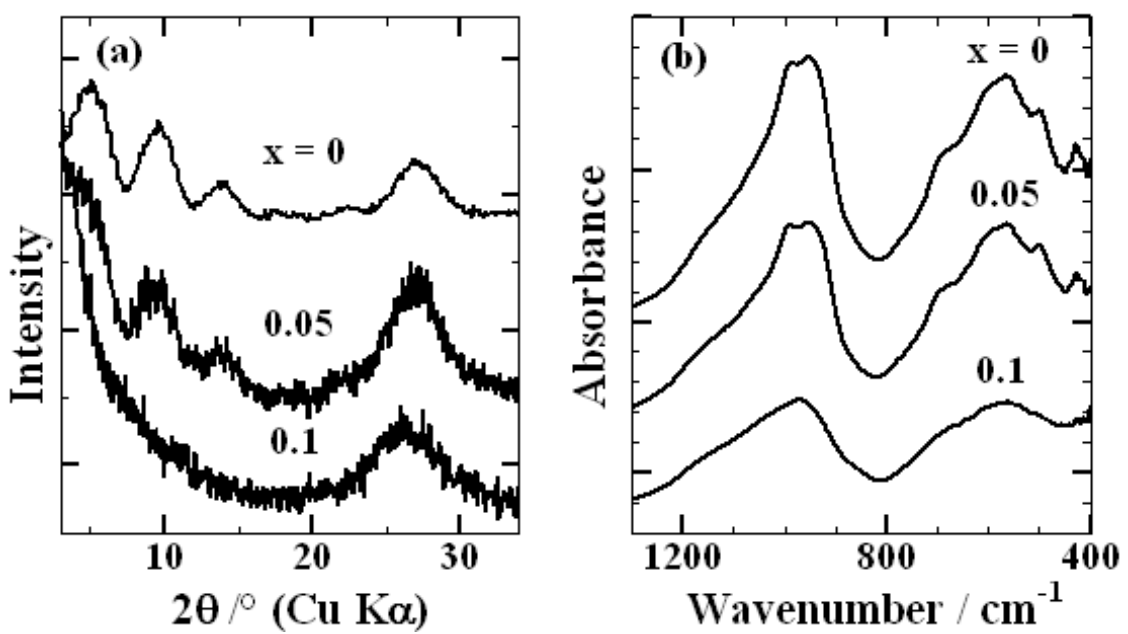

Figure 8. Characterization of Fe containing samples with $\mathrm{x}(=\mathrm{Fe} / \mathrm{Al}+\mathrm{Fe}$, atomic ratio $)=0,0.05,0.1$. XRD profiles (a) and FT-IR spectra (b) [23].

In order to investigate the state of iron ions in Fe-imogolite, it was compared with the $\mathrm{Fe}^{3+}$ ion adsorbed on imogolite The adsorbed $\mathrm{Fe}^{3+}$ ions sample was prepared by adsorbing $\mathrm{FeCl}_{3}$ onto imogolite from aqueous solution of $\mathrm{FeCl}_{3}$ and is called $\mathrm{FeCl}_{3} /$ imogolite. These samples are both reddish brown and the absorption bands of them were observed at the region above $15,000 \mathrm{~cm}^{-1}$ in diffuse reflectance ultraviolet visible (UV-VIS) spectra (Figure 9). The absorption bands of $\mathrm{Fe}^{3+}$ in many minerals are observed in this region.

It has been known that when the tetrahedral species of $\mathrm{Fe}^{3+}$ exist, the pre-edge peak appears strongly in X-ray absorption near edge structure (XANES) spectra. XANES spectra of Fe Kedge $(7.111 \mathrm{keV})$ are shown in Figure 10 . The pre-edge peak was not observed in the spectrum of Fe-imogolite nor $\mathrm{FeCl}_{3} /$ imogolite or $\mathrm{Fe}_{2} \mathrm{O}_{3}$. Thus it is clear that the state of iron in Fe-imogolite is octahedral $\mathrm{Fe}^{3+}$ ion from the results of UV-VIS and XANES spectra.

Figure 11 shows their Fourier transforms (FT) spectra of Fe-imogolite, $\mathrm{FeCl}_{3} /$ imogolite and $\mathrm{Fe}_{2} \mathrm{O}_{3}$. FT spectrum as radial structure function was obtained by Fourier transformation of $k^{3}$-weighted extended X-ray absorption fine structure (EXAFS) function. The FT spectrum of Fe-imogolite is different to that of $\mathrm{FeCl}_{3} /$ imogolite or $\mathrm{Fe}_{2} \mathrm{O}_{3}$. It can be concluded that the state of $\mathrm{Fe}^{3+}$ in $\mathrm{Fe}$-imogolite is different to the state of $\mathrm{Fe}^{3+}$ ions adsorbed on imogolite. We speculate that $\mathrm{Fe}^{3+}$ replaced the $\mathrm{Al}^{3+}$ sites in imogolite from these results.

The tapping mode AFM image of Fe-imogolite is shown in figure 12 [39]. The fibrous morphology was observed similar to the synthetic imogolite. It was found that the tube diameter was almost uniform and estimated to be 2.2-2.4 $\mathrm{nm}$ from section analysis. 


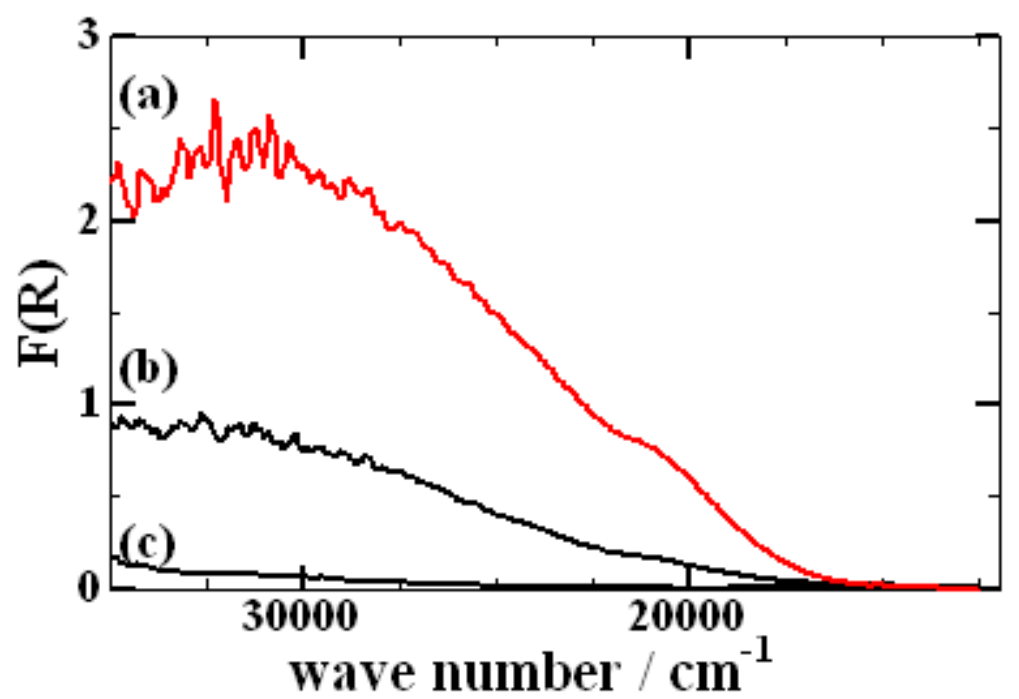

Figure 9. Diffuse reflectance UV-VIS spectra of (a) Fe-imogolite, (b) $\mathrm{FeCl}_{3} /$ imogolite and (c) imogolite [23].

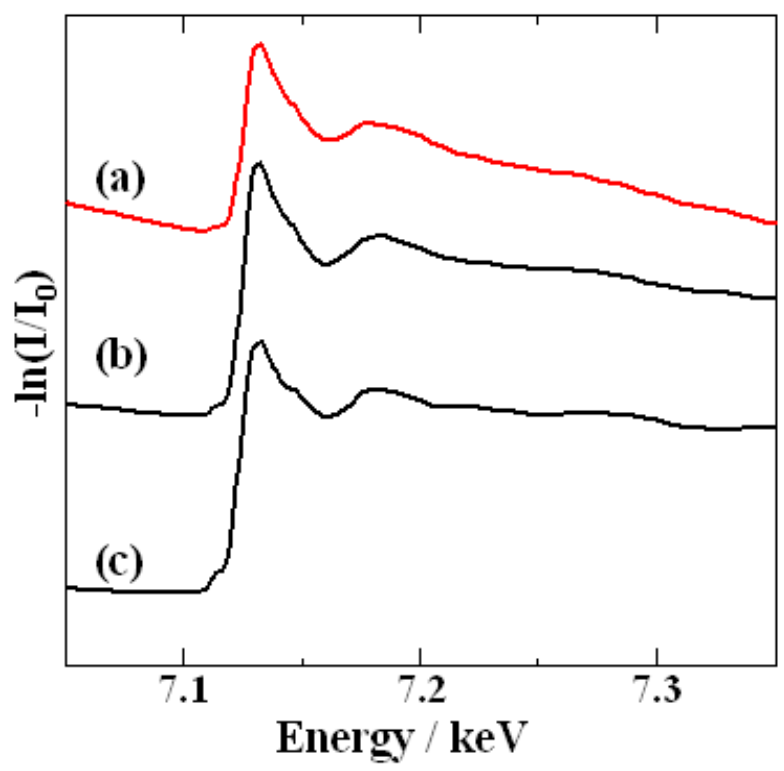

Figure 10. Fe K-edge XANES spectra of (a) Fe-imogolite, (b) $\mathrm{FeCl}_{3} /$ imogolite and (c) $\mathrm{Fe}_{2} \mathrm{O}_{3}$ (hematite) [23]. 


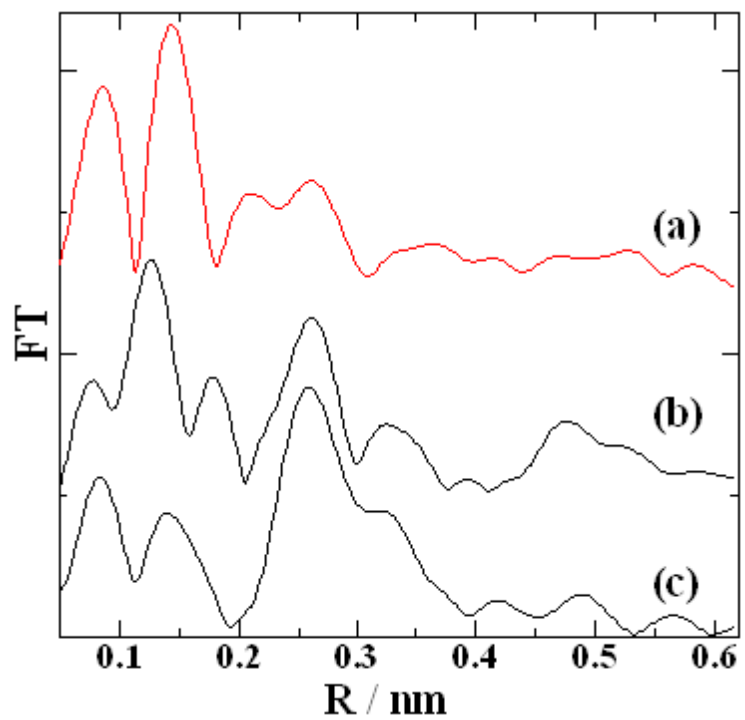

Figure 11. FT spectra of Fe K-edge $\mathrm{k}^{3}$-weighted EXAFS functions. (a) Fe-imogolite, (b) $\mathrm{FeCl}_{3} /$ imogolite and (c) $\mathrm{Fe}_{2} \mathrm{O}_{3}$ (hematite) [23].

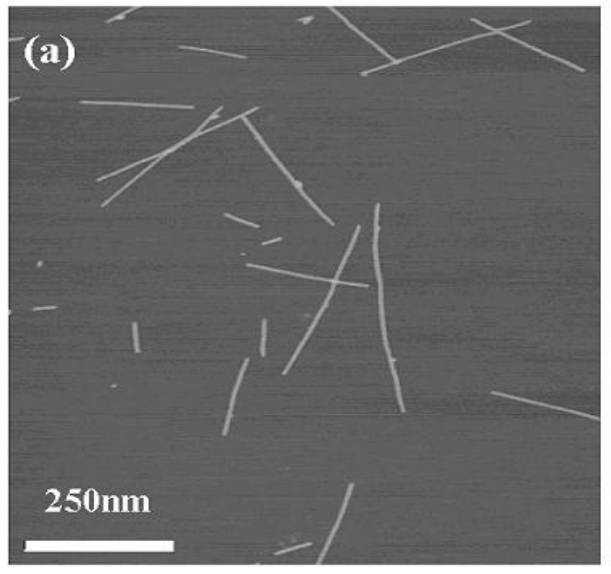

\section{(b) Section Analysis}

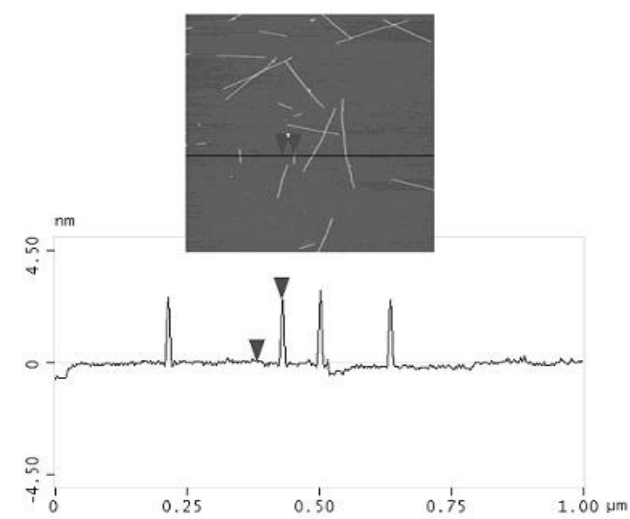

Figure 12. AFM image of Fe-imogolite (a) and section analysis (b). The height profile (right bottom) shows the height on black line in AFM picture (right top) [39].

\subsection{Oxidation of hydrocarbons using Fe-imogolite catalyst}

\subsubsection{Oxidation of cyclohexene [23]}

The oxidation of cyclohexene was carried out using cyclohexene, $\mathrm{H}_{2} \mathrm{O}_{2}$ and acetonitrile as a solvent with catalysts under being stirred at $50{ }^{\circ} \mathrm{C}$ for 24 hours. No product was detected without a catalyst. In the case of imogolite, 2-cyclohexene-1-ol and 1,2-epoxycyclohexane (EP) 
were produced slightly as stated above. EP was also detected in separate experiments using gibbsite, boehmite and $\mathrm{Al}_{2} \mathrm{O}_{3}$ as catalysts. Mandelli et al. [40] have reported the epoxidation of cyclohexene using $\mathrm{H}_{2} \mathrm{O}_{2}$ over $\mathrm{Al}_{2} \mathrm{O}_{3}$. It was attributed that these oxidation compounds may be produced on the outer surface of the imogolite. The oxidation reaction was promoted by Feimogolite and not only alcohol and epoxy compounds but trans-1,2-cyclohexanediol, cis-1,2cyclohexanediol and 2-cyclohexene-1-one were also obtained as products.

\subsubsection{Oxidation of aromatic hydrocarbon [23, 39]}

Phenol is one of the most important chemicals in the fields of fiber and medicine manufacturing. More than $90 \%$ of phenol is produced by the cumen process, which is a three-step process and produces acetone as a by-product. The development of a one-step process for phenol synthesis by the direct oxidation of benzene is important when concerned with green chemistry as an environment-friendly technique. It was found that benzene or other aromatic hydrocarbons were oxidized by $\mathrm{H}_{2} \mathrm{O}_{2}$ over Fe-imogolite. These results are described.

The reaction of benzene was carried out using $2 \mathrm{mmol}$ of benzene, $11 \mathrm{mmol}$ of $\mathrm{H}_{2} \mathrm{O}_{2}$ and 10 $\mathrm{mL}$ of acetonitrile as a solvent with $100 \mathrm{mg}$ of catalyst under being stirred at $60{ }^{\circ} \mathrm{C}$. The products were analyzed by GC-MASS. The conversion of $\mathrm{H}_{2} \mathrm{O}_{2}$ was determined by a volumetric analysis with $\mathrm{KMnO}_{4}$.

Figure 13 shows the results of oxidation reactions of benzene using $\mathrm{H}_{2} \mathrm{O}_{2}$ and compounds containing Fe. None of the oxidation products were detected without catalysts and with $\mathrm{FeCl}_{3} /$ imogolite, $\mathrm{Fe}_{2} \mathrm{O}_{3}$ (hematite) and $\alpha$-FeOOH (goethite) as a catalyst. It is an interesting finding that only phenol was obtained as an oxidation product by GC-Mass using Feimogolite [23].

The oxidation reactions of benzene using four solvents were examined. The results are summarized in Table 2. None of oxidation products were detected in the case of acetic acid and propionic acid as a solvent. It was found that acetonitrile was the most effective for this reaction among the examined solvents. Although the solution turned palish yellow using acetonitrile as a solvent, after the reaction the absorption due to the $\mathrm{Fe}^{3+}$ ion was not detected in UV-VIS absorption spectrum. It was suggested that the origin of the coloring could be phenolic tars that could not detected by GC-Mass. A conversion of $\mathrm{H}_{2} \mathrm{O}_{2}$ was high with all solvent and $\mathrm{H}_{2} \mathrm{O}_{2}$ efficiency was $2 \%$ using acetonitrile as a solvent. Thus, the decomposition of $\mathrm{H}_{2} \mathrm{O}_{2}$ was only caused by using other solvents except for acetonitrile.

The results of the oxidation reaction of aromatic hydrocarbons using Fe-imogolite as a catalyst are summarized in Table 3 [39]. Hydroquinone and catechol were produced as products from phenol by the oxidation with $\mathrm{H}_{2} \mathrm{O}_{2}$. $o$-Chlorophenol and $p$-chlorophenol were produced from chlorobenzene. When the side chain is $\mathrm{OH}$ group or $\mathrm{Cl}$ group, only the benzene ring was oxidized and the ortho and para isomers were obtained. Benzaldehyde, $o$ cresol and $p$-cresol were produced from toluene. In the case of benzaldehyde, most of the oxidation product was benzoic acid. 


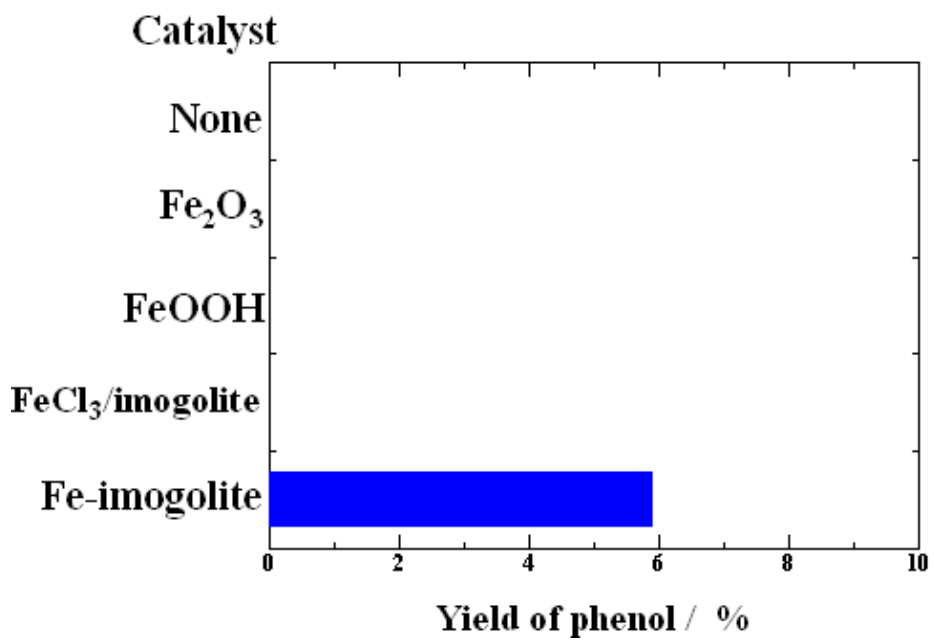

Figure 13. Results of the oxidation reactions of benzene using Fe-imogolite, $\mathrm{FeCl}_{3} / \mathrm{imogolite}, \mathrm{Fe}_{2} \mathrm{O}_{3}$ (hematite) or $\mathrm{FeOOH}$ (geothite) as a catalyst [23].

\begin{tabular}{cccc}
\hline \multirow{2}{*}{ Solvent } & \multicolumn{2}{c}{ Conversion $/ \%$} & \multirow{2}{*}{$\begin{array}{c}\text { Yield of } \\
\text { Phenol } / \%\end{array}$} \\
\cline { 2 - 3 } & benzene & $\mathrm{H}_{2} \mathrm{O}_{2}$ & \\
Acetonitrile & 10.6 & 93 & 10.6 \\
2-Propanol & tr. & 99 & tr. \\
Acetic acid & 0.0 & 95 & 0.0 \\
Propionic acid & 0.0 & 95 & 0.0 \\
\hline
\end{tabular}

Table 2. The effects of solvents on the oxidation of benzene [39].

Catalyst Fe-imogolite, temperature $=60^{\circ} \mathrm{C}$, time $=6 \mathrm{~h}$, benzene $=2 \mathrm{mmol}$,

$\mathrm{H}_{2} \mathrm{O}_{2}=11.5 \mathrm{mmol}$, solvent $=10 \mathrm{~mL}$

When the side chain is a hydrocarbon group such as methyl, both the benzene ring and the side chain group were oxidized. It was found that the side chain group was more easily oxidized.

Monfared and Amouei [41] have reported direct oxidation reactions of benzene or some aromatic hydrocarbon compounds over $\mathrm{Fe}^{3+}$ loaded $\mathrm{Al}_{2} \mathrm{O}_{3}\left(\mathrm{Fe}^{3+}-\mathrm{Al}_{2} \mathrm{O}_{3}\right)$ with $\mathrm{H}_{2} \mathrm{O}_{2}$ in acetonitrile. In their system, however, $o$-cresol and $m$-cresol as main products were produced from toluene and no oxidation compounds were produced from phenol. It has been shown that the oxidation property of a Fe-imogolite catalyst is different from that of a $\mathrm{Fe}^{3+}-\mathrm{Al}_{2} \mathrm{O}_{3}$ catalyst.

\subsubsection{Oxidation of cyclohexane $[42,43]$}

Oxidation of cycloxane under mild conditions have been very interesting and have attempted widely [44]. Since the oxidation takes place not only on aromatic rings but on 
methyl groups by $\mathrm{H}_{2} \mathrm{O}_{2}$ in acetonitrile over Fe-imogolite catalysts, other organic compounds such as saturated hydrocarbons could be oxidized under this reaction condition. We examined the oxidation of cyclohexane using this catalyst.<smiles>Oc1ccccc1</smiles>

phenol<smiles>Oc1ccccc1O</smiles>

catechol (13.7)<smiles>Oc1ccc(O)cc1</smiles>

hydroquinone (15.9)<smiles>Clc1ccccc1</smiles><smiles>Oc1ccc(Cl)cc1</smiles><smiles>Oc1ccccc1Cl</smiles>

chlorobenzene

p- chlorophenol (9.7)

o- chlorophenol (4.8)<smiles>Cc1ccccc1</smiles><smiles>O=Cc1ccccc1</smiles><smiles>Cc1ccc(O)cc1</smiles><smiles>Cc1ccccc1O</smiles>

toluene

benzaldehyde (5.8)

$p$ - $\operatorname{cresol}(2.2)$

$o$ - cresol (1.3)<smiles>O=Cc1ccccc1</smiles><smiles>O=C(O)c1ccccc1</smiles>

benzaldehyde

benzoic acid (71.7)

2-hydroxy-benzaldehyde (1.7)

Table 3. Oxidation reactions of aromatic hydrocarbons with $\mathrm{H}_{2} \mathrm{O}_{2}$ over Fe-imogolite [39].

*The yield of product is estimated using the ratio of peak area of GC-Mass.

Temperature $=60^{\circ} \mathrm{C}$, time $=6 \mathrm{~h}$, reactant $=2 \mathrm{mmol}, \mathrm{H}_{2} \mathrm{O}_{2}=11.5 \mathrm{mmol}$, solvent $=10 \mathrm{~mL}$ 
The reaction of cyclohexane was carried out using $2 \mathrm{mmol}$ of cyclohexane, $10 \mathrm{mmol}$ of $\mathrm{H}_{2} \mathrm{O}_{2}$ and $10 \mathrm{ml}$ of acetonitrile as a solvent with $50 \mathrm{mg}$ of catalyst under being stirred at $60{ }^{\circ} \mathrm{C}$ for 3 hours. The products were analyzed by GC-Mass and GC with FID detector. The oxidation products were hardly detected without catalysts. With Fe-containing imogolite as a catalyst, this reaction was promoted and three oxidation products were created. Two compounds were easily identified by retention time of standard reagents such as cyclohexanone and cyclohexanol among these products. Another is speculated as cyclohexyl hydroperoxide from fragmentation patterns in the mass spectrum. It was reported [45] that cyclohexyl hydroperoxide was prepared efficiently and selectively using cyclohexane and $\mathrm{H}_{2} \mathrm{O}_{2}$ over $\mathrm{Fe}^{3+}$ ion-changed montmorillonite. We identified one of the oxidation products as cyclohexyl hydroperoxide by the compound obtained following this examination. The conversion of cyclohexane was ca. $25 \%$.

The cyclohexyl hydroperoxide was produced immediately as soon as the reaction started. Additionally, it was detected only in oxidation reactions with $\mathrm{Fe}_{2} \mathrm{O}_{3}$ or $\alpha-\mathrm{FeOOH}$ as a catalyst. It was found that cyclohexanone and cyclohexanol were produced via cyclohexyl hydroperoxide as an intermediate which was obtained by reacting cyclohexane and $\mathrm{H}_{2} \mathrm{O}_{2}$ (Figure 14).

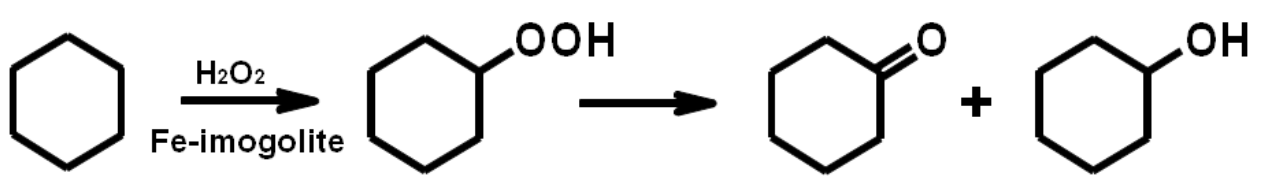

Figure 14. Oxidation reactions of cyclohexane using $\mathrm{H}_{2} \mathrm{O}_{2}$ over Fe-imogolite [42].

\section{Conclusion}

Fe-imogolite was synthesized using $\mathrm{Na}_{4} \mathrm{SiO}_{4}, \mathrm{AlCl}_{3}$ and $\mathrm{FeCl}_{3}$ with the atomic ratio $\mathrm{Fe} /$ $(\mathrm{Al}+\mathrm{Fe})=0.05$ and applied as a liquid-phase oxidation catalyst with hydrogen peroxide.

The XRD profile and FT-IR spectrum of this material were similar to the synthetic imogolite. AFM images showed fibrous morphology with ca. $2 \mathrm{~nm}$ of diameter. UV-VIS and X-ray absorption spectra revealed the state of $\mathrm{Fe}^{3+}$ to be in the octahedral coordination. It was found that Fe-imogolite played as an oxidation catalyst of some hydrocarbons such as cyclohexane, benzene, phenol, toluene and cyclohexane with hydrogen peroxide. The oxidation reaction of cyclohexene was promoted by using Fe-imogolite instead of imogolite as a catalyst. It gave 2-cyclohexene-1-ol, 1,2-epoxycyclohexane, 1,2-cyclohexanediol and 2cyclohexene-1-one as products. Phenol was produced by the oxidation reaction of benzene. The benzene ring in the aromatic hydrocarbons such as phenol, chlorobenzene, toluene and benzaldehyde was oxidized. Moreover, when the side-chain is a hydrocarbon group, sidechain group was also oxidized. It could be more easily oxidized than the benzene ring. Cyclohexyl hydroperoxide, Cyclohexanone and cyclohexanol were obtained as oxidation products of cyclohexane. It was clarified found that cyclohexanone and cyclohexanol were 
produced via cyclohexyl hydroperoxide. The possibility of Fe-imogolite as an oxidation catalyst is shown. However, its reaction mechanism has not been clarified yet. It is necessary to investigation the catalytic properties and the structure of Fe-imogolite further.

\section{Author details}

Masashi Ookawa

Department of Chemistry and Biochemistry, Numazu National College of Technology, Numazu, Japan

\section{References}

[1] Yoshinaga N., Aomine S. (1962) Imogolite in some Ando soils, Soil Sci. Plant Nutr. 8: 114-121.

[2] Cradwick P. D. G., Farmer V. C., Rucell J. D., Masson C. R., Wada K., Yoshinaga N., (1972) Imogolite, a Hydrated Aluminum Silicate of Tubular Structure Nature Phys. Sci. 240:187-189.

[3] Bursill L. A., Peng J. L., Burgeois L. N. (2000) Imogolite: an aluminosilicate nanotube materials, Philos. Mag., 80: 105-117.

[4] Koenderink G.H., Kluijtmans S. G J M, Philipse A. P,(1999) On the Synthesis of Colloidal Imogolite Fibers, J. Colloid. Interface Sci. 216: 429-431.

[5] Hu J., Kannangara G.S. K., Wilson M.A., Reddy N., (2004) The fused silicate rote to protoimogolite and imogolite, J. Non-cryst. Solids, 347:224-230.

[6] Suzuki M., Ohashi F., Inukai K., Maeda M., Tomura S. (2000) Synthesis of Allophane and Imogolite from Inorganic Solution - Influence of Co-Existing lon Concentration and Titration Rate on Forming Precursor -, Nendo Kagaku (J. Clay Sci. Soc. Japan), 40:1-14.

[7] Suzuki M., Inukai K., (2010) Synthesis and Applications of Imogolite Nanotubes, in: Kijima T. editors, Inorganic and Metallic Nanotubular Materials, Topics in Applied Physics, 117: Springer pp. 159-167, DOI: 10.1007/978-3-642-03622-4_12

[8] Levard C., Masion A., Rose J., Doelsch E., Borschneck D., Dominici C., Ziarelli F., Bottero J. -Y., (2009) Synthesis of Imogolite Fibers from Decimolar Concentration at Low Temperature and Ambient Pressure: A Promising Route for Inexpensive Nanotubes, J. Am. Chem. Soc. 131:17080-17081.

[9] Abidin Z., Matsue N., Henmi T. (2008) A New Method for Nano Tube Imogolite Synthesis, Jpn. J. Appl. Phys. 47:5079-5082.

[10] Mukherjee S., Bartlow V. M., Nair S. (2005) Phenomenology of the Growth of SingleWalled Aluminosilicate and Aluminogermanate Nanotubes of Precise Dimensions, Chem. Mater., 17, 4900-4909.

[11] Donkai N., Miyamoto T., Kokubo T., Tanei H. (1992) Preparation of transparent mullitesilica film by heat-treatment of imogolite, J. Mater. Sci., 27: 6193-6196. 
[12] MacKenzie K. J. D., Bowden M. E., Brown I. W. M., Meinhold R. H., (1989) Structure and thermal transformations of imogolite studied by ${ }^{29} \mathrm{Si}$ and ${ }^{27} \mathrm{Al}$ high-resolution solidstate nuclear magnetic resonance, Clays Clay Miner. 37: 317-324.

[13] Tamura, K. And Kawamura K. (2002) Molecular Dynamics Modeling of Tubular Aluminum Silicate: Imogolite, J. Phys. Chem. B, 106: 271-278.

[14] Luciana Guimarães L., Andrey N. Enyashin A. N., Frenzel J., Heine T., Duarte H. A., Seifert G. (2007) Imogolite Nanotubes: Stability, Electronic, and Mechanical Properties, ACS Nano, 1:362-368.

[15] Fernando Alvarez-Ramírez, (2007) Ab initio simulation of the structural and electronic properties of aluminosilicate and aluminogermanate natotubes with imogolite-like structure, Phys. Rev. B 76:125421-125434.

[16] Yamamoto K., Otsuka H., Wada S.-I., Sohn D., Takahara A., (2005) Preparation and properties of [poly(methyl methacrylate)/imogolite] hybrid via surface modification using phosphoric acid ester, Polymer, 46, 12386-12392.

[17] Yah W. O., Yamamoto K., Jiravanichanun N. , Otsuka H., Takahara A. (2010) Imogolite Reinforced Nanocomposites: Multifaceted Green Materials, Materials, 3:1709-1745; doi:10.3390/ma3031709.

[18] Ohashi F., Tomura S., Akaku A., Hayashi S., Wada S. -I., (2004)Characterization of synthetic imogolite nanotubes as gas strage, J. Mater. Sci., 39: 1799-1801.

[19] Ackerman W. C., Smith D. M., Huling J. C., Kim Y. -H., Bailey J. K., Brinker C. J., (1993) Gas/Vapor Adsorption in Imogolite: A Microporous Tubular Aluminosilicate, Langmuir, 9, 1051-1057.

[20] Suzuki M., Ohashi F., Inukai K., Maeda M., Tomura S., Mizota T., (2001) Hydration Enthalpy Measurement and Evaluation as Heat Exchangers of Allophane and Imogolite, J. Ceram. Soc. Japan, 109: 681- 685.

[21] Imamura S., Hayashi Y., Kajiwara K., Hoshino H., Kaito C., (1993) Imogolite: A Possible New Type of Shape-Selective Catalyst, Ind. Eng. Chem. Res., 32: 600-603.

[22] Imamura S., Kokubu K., Yamashita T., Okamoto Y., Kajiwara K., Kanai H., (1996) Shape-Selective Copper Loaded Imogolite Catalyst, J. Catal., 160: 137-139.

[23] Ookawa M., Inoue Y., Watanabe M., Suzuki M., Yamaguchi T. (2006) Synthesis and Characterization of Fe containing Imogolite, Clay Sci., 12, Supplement 2: 280-284.

[24] Farmer V. C., Fraser A. R., Tait J. M. (1977) Synthesis of imogolite: A tubular aluminum silicate polymer, J. Chem. Soc. Chem. Comm., 13: 462-463.

[25] Wada S. -I., Eto A., Wada K. (1979) Synthetic allophane and imogolite, J. Soil Sci., 30: 347-355.

[26] Tani M., Liu C., Huang P. M. (2004) Atomic force microscopy of synthetic imogolite, Geoderma, 118: 209-220.

[27] Ohrai, Y., Gozu, T., Yoshida, S., Takeuchi, O., Iijima, S., Shigekawa, H. (2005) Atomic force microscopy on imogolite, aluminosilicate nanotube, adsorbed on $\mathrm{Au}(111)$ surface, Jpn. J. Appl. Phys., 44:5397-5399. 
[28] Mccutcheon A., Hu J., Kannangara G. S. K., Wilson M. A., Reddy N., (2005) ${ }^{29}$ Si labelled nanoaluminosilicate imogolite, J. Non-Cryst. Solids, 351: 1967-1972.

[29] Wada S. -I., Wada K. (1982) Effects of the substitution of germanium for silicon in imogolite, Clays Clay Miner., 30: 123-128.

[30] Barron P. F., Wilson M. A., Campbell A. S., Frost R. L., (1982) Detection of imogolite in soils using solid state ${ }^{29}$ Si NMR, Nature 299: $616-618$.

[31] Ildefonse P., Kirkpatrick R. J., Montez B., Calas G., Flank A. M., Lagarde P., (1994) Investigated structure of imogolite using ${ }^{27} \mathrm{Al}$ magic-angle-spinning (MAS) NMR and aluminum X-ray absorption near edge structure, Clay. Clay Min., 42:276-287.

[32] Goodman B. A., Russell J. D., Montez B., Oldfield E., Kirkpatrick R. J., Structural studies of imogolite and allophanes by aluminum-27 and silicon-29 nuclear magnetic resonance spectroscopy, Phys. Chem. Minerals, 12:342-346.

[33] Hiradate S., Wada S. -I. (2005) Weathering process of volcanic glass to allophane determined by ${ }^{27} \mathrm{Al}$ and ${ }^{29} \mathrm{Si}$ solid-state NMR, Clay. Clay Min., 53:401-408.

[34] Hatakeyama M., Hara T., Ichikuni N., Shimazu S., (2011) Characterization of HeatTreated Synthetic Imogolite by ${ }^{27} \mathrm{Al}$ MAS and ${ }^{27} \mathrm{Al}$ MQMAS Solid-State NMR Bull. Chem. Soc. Jpn., 84: 656-659.

[35] Henmi T., Wada K.,(1974) Surface acidity of imogolite and allopahne, Clay Minerals, 10: 231-245.

[36] Bonelli B., Ilaria Bottero I., Ballarini N., Passeri S., Cavani F., Garrone E., (2009) IR spectroscopic and catalytic characterization of the acidity of imogolite-based systems, J. Catal.,264: 15-30.

[37] Ookawa M., Onishi Y., Fukukawa S., Matsumoto K., Watanabe M., Yamaguchi T., Suzuki M. (2006) Catalytic Property of Synthetic Imogolite, Nendo Kagaku (J. Clay Sci. Soc. Japan), 45: 184-187.

[38] Ohnishi R., Tanabe K., Morikawa S., Nishizaki T. (1974) Isomerization of 2-Pinene Catalyzed by Solid Acids, Bull. Chem. Soc. Jpn. 47: 571 - 574.

[39] Ookawa M., Takata Y., Suzuki M., Inukai K., Maekawa T., Yamaguchi T. (2008) Oxidation of aromatic hydrocarbons with $\mathrm{H}_{2} \mathrm{O}_{2}$ catalyzed by a nano-scale tubular aluminosilicate, Fe-containing imogolite, Res. Chem. Inter., 34: 679-685.

[40] Mandelli D., van Vliet M. C.A, Sheldon R. A., Schuchardt U., (2001) Alumina-catalyzed alkene epoxidation with hydrogen peroxide, Appl. Cat. A, 219:209-213

[41] Monfared H. H., Amouei Z. (2004) Hydrogen peroxide oxidation of aromatic hydrocarbons by immobilized iron(III), J. Mol. Cat. A, 217: 161-164.

[42] Ookawa M., Nagamitsu Y., Oda M., Takata Y., Yamaguchi T., Maekawa T. (2008) Catalytic properties of Fe-containing imogolite in cyclohexane oxidation, Interfaces Against Pollutions 2008 Programs \& Abstracts: 24.

[43] Ookawa M., Nagamitsu, Yamaguchi T., Maekawa T. (2007) Oxidation of cyclohexane Catalyzed by Fe-containing imogolite, Abstracts ISSEM2007 International Symposium on Sustainable Energy \& Materials: 47. 
[44] Schuchardt U., Cardoso D., Sercheli R., Pereira R., da Cruz R. S., Guerreiro M.C., Mandelli D., Spinacé E. V., Pires E. L. (2000) Cyclohexane oxidation continues to be a challenge, Appl. Cat. A 211:1-17.

[45] Ebitani K., Ide M., Mitsudome T., Mizugaki T., Kaneda K. (2002) Creation of a chain-like cationic iron species in montmorillonite as a highly active heterogeneous catalyst for alkane oxygenations using hydrogen peroxide, Chem. Comm.: 690-691. 